\title{
Program asuhan gizi olahraga (PAGO) atlet sepatu roda sebagai strategi memperbaiki profil status gizi, biokimia, dan kualitas asupan
}

\section{Fillah Fithra Dieny", Firdananda Fikri Jauharany, Ayu Rahadiyanti, Deny Yudi Fitranti, A. Fahmy Arif Tsani, Dewi Marfu'ah Kurniawati}

\author{
Departemen Ilmu Gizi, Universitas Diponegoro Semarang. Jalan Prof. Soedarto No.13, Tembalang, \\ Kec. Tembalang, Kota Semarang, Jawa Tengah 50275, Indonesia \\ * Corresponding Author. Email: fillahdieny@gmail.com
}

Received: September 30, 2020; Accepted: August 2, 2021; Published: September 25, 2021

\begin{abstract}
Abstrak: Penelitian ini bertujuan menganalisis pengaruh pemberian intervensi gizi berupa edukasi dan konseling gizi pada atlet sepatu roda remaja terhadap status gizi, status hidrasi, status biokimia, dan asupan gizi. Penelitian one group pre and post test design melibatkan 11 atlet di Klub Sepatu Roda Kairos Semarang. Variabel terikat adalah profil antropometri (berat badan, tinggi badan, fat mass, massa otot, body water), status hidrasi, status biokimia (kadar gula darah puasa, asam urat, kolesterol, hemoglobin), dan asupan makan. Uji Wilcoxon digunakan untuk menganalisis perbedaan profi antropometri, status hidrasi, status biokimia, dan asupan makan subjek antara sebelum dan sesudah intervensi. Terdapat perbedaan yang signifikan pada berat badan $(\mathrm{p}=0,029)$, fat mass $(\mathrm{p}=0,003)$, status hidrasi subjek sebelum latihan $(\mathrm{p}=0,026)$, kadar gula darah $(\mathrm{p}=0,005)$, kadar hemoglobin $(\mathrm{p}=0,007)$, asupan karbohidrat $(\mathrm{p}=0,029)$ dan asupan seng $(\mathrm{p}=0,049)$ sebelum dan setelah intervensi. Program Asuhan Gizi Olahraga (PAGO) pada atlet sepatu roda terbukti berdampak pada perbaikan beberapa profil antropometri, status biokimia, dan asupan makan.
\end{abstract}

Kata Kunci: sepatu roda, asuhan gizi olahraga, profil antropometri, biokimia, asupan makan

\section{Program for inline skating athletes as strategies to improve the profile of nutritional status, biochemistry and quality of food intake}

\begin{abstract}
This study aims to determine the effect of nutrition intervention in the form of nutrition education and counseling for adolescent inline skating athletes on nutritional status, hydration status, biochemical status, and nutritional intake. Methods: One group pre and post test design research on 11 athletes at the Kairos Wheeled Shoes Club Semarang. The dependent variables were anthropometric profiles (body weight, height, fat mass, muscle mass, body water), hydration status, biochemical status (fasting blood sugar levels, uric acid, cholesterol, hemoglobin), and food intake. The Wilcoxon test was used to analyze differences in anthropometric profile, hydration status, biochemical status, and food intake of subjects between before and after the intervention, Results: There was a significant difference in body weight $(p=0.029)$, fat mass $(p=$ $0.003)$, hydration status subjects before exercise $(p=0.026)$, blood sugar levels $(p=0.005)$, hemoglobin levels $(p=0.007)$, carbohydrate intake $(p=0.029)$ and zinc intake $(p=0.049)$ before and after the intervention. Sports Nutrition Care Programme to inline skate athletes is proven to have an impact on anthropometric profile, biochemical status, and intake.
\end{abstract}

Keywords: inline skating, sports nutrition care, anthropometric profile, biochemistry, food intake

How to Cite: Dieny, F, F., Jauharany, F, F., Rahadiyanti, A., Fitranti, D, Y., Tsani, A. F. A., \& Kurniawati, D. M. (2021). Program asuhan gizi olahraga (PAGO) atlet sepatu roda sebagai strategi memperbaiki profil status gizi, biokimia, dan kualitas asupan. Jurnal Keolahragaan, 9(2), 148-158. doi: https://doi.org/10.21831/jk.v9i2.34747

\section{PENDAHULUAN}

Olahraga sepatu roda saat ini mengalami perkembangan semakin besar dan telah banyak digemari oleh berbagai kalangan masyarakat. Permainan sepatu roda (inline skating) atau selancar roda sebaris menjadi salah satu olahraga yang populer di dunia termasuk di Indonesia. Sepatu roda merupakan salah satu cabang olahraga yang banyak ditekuni dengan tujuan menjadi atlet yang berprestasi. Kota Semarang merupakan salah satu kota yang banyak melahirkan atlet sepatu roda. Hal ini dibuktikan dengan 


\section{Jurnal Keolahragaan 9 (2), 2021 - 149}

Fillah Fithra Dieny, Firdananda Fikri Jauharany, Ayu Rahadiyanti, Deny Yudi Fitranti, A. Fahmy Arif Tsani, Dewi Marfu'ah Kurniawati

banyaknya medali yang diperoleh atlet cabang olahraga sepatu roda Provinsi Jawa Tengah pada PON XVI 2004- PON XVIII 2012. Selain itu, pada kejuaraan SEA GAMES tahun 2011 atlet terbanyak yang mewakili Indonesia dan menyumbangkan 5 medali emas merupakan atlet sepatu roda yang berasal dari Provinsi Jawa Tengah (Hermawan, 2015).

Menciptakan atlet dengan prestasi yang maksimal membutuhkan serangkaian proses mulai dari mencari bakat atlet, melakukan pembinaan prestasi yang panjang untuk mencapai performa dan prestasi yang baik (Saputra \& Indra, 2019). Ada beberapa faktor yang harus dimiliki oleh seorang atlet, diantaranya yaitu kemampuan teknik, taktik, fisik, dan psikologis yang baik. Performa seorang atlet didukung oleh faktor internal dan faktor eksternal. Faktor internal merupakan pendukung tercapainya prestasi olahragawan, hal ini disebabkan karena faktor ini mampu memberikan dorongan stabil dan kuat yang tercipta dari dalam diri atlet itu sendiri. Faktor internal terdiri dari motivasi dan bakat. Sedangkan faktor eksternal merupakan penguat terhadap kualitas latihan yang akan mempengaruhi prestasi. Faktor eksternal terdiri dari kemampuan dan kepribadian pelatih, fasilitas, hasil riset, dan asupan zat gizi. Selain itu ada faktor lingkungan pertandingan yang terdiri dari pelatih, keuangan, alat, tempat, perlengkapan, organisasi, lingkungan, dan adanya partisipasi pemerintah (Suharno, 1992).

Dalam menjaga kesehatan, adaptasi latihan dan meningkatkan stamina selama sesi latihan dan perlombaan, kecukupan kebutuhan gizi seperti karbohidrat, protein, lemak, serat, cairan dan asupan zat gizi mikro sangat penting (Miza Hapsari Sakti Titis Penggalih \& Huriyati, 2007) . Gizi merupakan salah satu faktor penunjang besarnya aktivitas latihan dan performa saat pertandingan. Akan tetapi, faktor gizi masih kurang diperhatikan dan dipahami baik oleh atlet, pihak training center, pelatih, maupun orang tua atlet.

Disisi lain, masa remaja merupakan masa yang berisiko mengalami masalah gizi, hal ini ditandai dengan perubahan psikologis, fisiologis, dan sosial (Rhaisa, Carvalho, Vargas, Chagas, \& Toral, 2017). Asupan gizi yang cukup diperlukan oleh seorang remaja untuk mendukung pertumbuhan yang sangat cepat dan memenuhi potensi fisiologisnya (Nelson, Story, Larson, Neumark-Sztainer, \& Lytle, 2008). Akan tetapi, atlet remaja ,elakukan pemilihan makanan yang tidak selalu sehat atau pengetahuan yang kurang memadai tentang gizi guna mendukung perfomanya (Patton-Lopez, Manore, Branscum, Meng, \& Wong, 2018). Beberapa penelitian terdahulu telah menemukan tentang pentingnya gizi yang tepat dalam performa atlet, akan tetapi masih banyak sekali atlet yang tidak mengikuti diet yang memenuhi standar gizi olahraga (Zuniga, Downey, McCluskey, \& Rivers, 2017).

Atlet remaja melakukan latihan dengan intensitas tinggi membutuhkan asupan gizi yang sesuai dengan kebutuhan guna mengoptimalkan dan tumbuh kembangnya. Meski memiliki kebutuhan gizi yang lebih tinggi, atlet remaja juga rentan mengalami masalah gizi, termasuk melewatkan waktu makan, fad diet, mengalami gangguan makan, dan mengkonsumsi suplemen olahraga yang menjanjikan peningkatan performa (Carl, Johnson, Martin, \& AAP COUNCIL ON SPORTS MEDICINE AND FITNESS., 2017). Oleh karena itu, diperlukan edukasi dan konseling gizi yang efektif untuk dapat membantu atlet remaja memilih makanan padat gizi yang bervariasi, membantu atlet remaja menjaga hidrasi yang tepat dan membantu atlet remaja memilih makanan serta snack yang sesuai dengan kebutuhan gizinya (Bingham, Borkan, \& Quatromoni, 2016). Hasil survey awal pada kelompok sepatu roda Kairos ditemukan $80 \%$ atlet memiliki asupan energi, zat gizi makro dan mikro yang kurang. Hal ini disebabkan kurangnya pengetahuan gizi tentang kebutuhan atlet, rekomendasi menu dan bagaimana mencukupi kebutuhan zat gizi pada atlet sepatu roda. Penelitian ini bertujuan untuk melihat pengaruh pemberian intervensi gizi berupa edukasi dan konseling gizi pada atlet sepatu roda remaja terhadap status gizi, status hidrasi, status biokimia, dan asupan gizinya.

\section{METODE}

Penelitian ini merupakan penelitian eksperimental dengan one group pre and post test design yang dilakukan di Klub Sepatu Roda Kairos Semarang, yang melibatkan 11 subjek berusia remaja. Rangkaian kegiatan penelitian dimulai sejak bulan Oktober 2019 sampai dengan Juli 2020 pada atlet sepatu roda dengan usia 12-20 tahun. Pemilihan subjek penelitian diambil dengan teknik consecutive sampling, seluruh atlet sepatu roda di Klub Kairos yang telah memenuhi kriteria inklusi dan bersedia mengikuti rangkaian penelitian dengan menjalani intervensi sampai dengan selesai.

Program Asuhan Gizi Olahraga merupakan proses asuhan gizi olahraga yang memiliki beberapa tahapan meliputi kegiatan ADIME yang terdiri dari assessment (pengkajian) gizi, diagnosis gizi, 


\section{Jurnal Keolahragaan 9 (2), 2021 - 150}

Fillah Fithra Dieny, Firdananda Fikri Jauharany, Ayu Rahadiyanti, Deny Yudi Fitranti, A. Fahmy Arif Tsani, Dewi Marfu'ah Kurniawati

intervensi gizi, monitoring dan evaluasi gizi. Intervensi yang dilakukan berupa edukasi dan konseling gizi. Edukasi gizi diberikan dengan perpaduan metode yaitu ceramah, diskusi dan tanya jawab sebanyak 1x pertemuan dan konseling gizi kelompok pada pelatih, atlet dan orang tua sebanyak 4x serta konseling gizi pada masing masing atlet sebanyak 4x. Proses Edukasi dan konseling Gizi dilakukan di Laboratorium Penilaian Status Gizi dan Konseling Gizi Departemen Ilmu Gizi FK UNDIP. Materi edukasi gizi yang diberikan terkait peran gizi olahraga dalam menunjang performa, pengaturan kebutuhan gizi atlet, kebutuhan cairan dan rekomendasi menu sehari untuk mencukupi kebutuhan gizi. Selanjutnya subjek dapat berkonsultasi setiap hari melalui sosial media WhatsApp. Intervensi edukasi dan konseling gizi diberikan untuk merubah perilaku makan dan minum atlet yang nantinya diukur dengan metode food recall.

Pengambilan data berupa pengukuran antropometri, pengukuran status hidrasi, status biokimia, dan asupan gizi subjek. Pengambilan data dilakukan dua kali, sebelum intervensi dan setelah intervensi. Pengukuran antropometri yang dilakukan adalah pengukuran berat badan, tinggi badan dan persen lemak tubuh. Berat badan diukur dengan timbangan injak digital dengan ketelitian 0,1 kg. Tinggi badan diukur dengan microtoise dengan ketelitian $0,1 \mathrm{~cm}$, dengan posisi berdiri tegak dan pandangan lurus ke depan. Data persen lemak tubuh diukur menggunakan alat Bioelectrical Impedance Analysis (BIA). Saat pengukuran berat badan dan persen lemak tubuh subjek melepas alas kaki dan mengenakan pakaian seminimal mungkin.

Pengukuran status hidrasi sebelum dan setelah latihan menggunakan metode warna urin. Pengukuran status biokimia meliputi kadar gula darah puasa, kadar asam urat, dan kadar kolesterol menggunakan pemeriksaan darah melalui kapiler dengan strip test. Perhitungan asupan makan dan cairan subjek dalam sehari diperoleh melalui wawancara pada subjek menggunakan kuesioner food recall 3x24 jam yang dilakukan sebelum dan setelah intervensi dilakukan.

Analisis univariat digunakan untuk mendeskripsikan karakteristik subjek berupa jenis kelamin, tingkat pendidikan, jenis tempat tinggal, dan uang saku. Uji normalitas menggunakan Saphiro-Wilk menunjukkan variabel dalam penelitian ini berdistribusi normal. Uji Paired t-test digunakan untuk menganalisis adanya perbedaan profil antropometri, status hidrasi, profil biokimia, dan asupan makan subjek antara sebelum dan setelah intervensi. Analisis statistika menggunakan software SPSS versi 22.0.

\section{HASIL DAN PEMBAHASAN}

Tabel 1 menunjukkan karakteristik subjek yang terlibat dalam penelitian ini. Sebanyak 63,6\% subjek dalam penelitian adalah laki-laki dan sebanyak 36,4\% subjek adalah perempuan. Berdasarkan tingkat pendidikan, diketahui 45,5\% subjek merupakan siswa SMP. Sebanyak 36,4\% subjek adalah siswa SMA, dan sebanyak $18,1 \%$ subjek merupakan mahasiswa. Sebagian besar subjek dalam penelitian ini, yaitu sebanyak $72,7 \%$ tinggal di rumah bersama orang tua dan hanya $27,3 \%$ subjek yang tinggal di asrama. Hasil wawancara terkait uang saku subjek, diketahui sebagian besar subjek, yaitu 54,5\% menerima uang saku $<$ Rp 1.000.000 / bulan.

Tabel 1. Karakteristik Subjek Penelitian

\begin{tabular}{lll}
\hline Kategori & n & \% \\
\hline Jenis Kelamin & & \\
$\quad$ Laki-Laki & 7 & 63,6 \\
$\quad$ Perempuan & 4 & 36,4 \\
Tingkat Pendidikan & & \\
$\quad$ Siswa SMP & 5 & 45,5 \\
$\quad$ Siswa SMA & 4 & 36,4 \\
$\quad$ Mahasiswa & 2 & 18,1 \\
Jenis Tempat Tinggal & & \\
$\quad$ Rumah & 8 & 72,7 \\
$\quad$ Asrama & 3 & 27,3 \\
Uang Saku (Bulan) & & \\
$\quad$ < Rp.1000.000,- & 6 & 54,5 \\
$\quad$ > Rp.1000.000,- Sd & 3 & 27,3 \\
$\quad$ Rp.2000.000,- & & \\
$\quad$ > Rp.2000000,- & 2 & 18,2 \\
\hline
\end{tabular}


Jurnal Keolahragaan 9 (2), 2021 - 151

Fillah Fithra Dieny, Firdananda Fikri Jauharany, Ayu Rahadiyanti, Deny Yudi Fitranti, A. Fahmy Arif Tsani, Dewi Marfu'ah Kurniawati

Berikut ini merupakan alur kegiatan Program Asuhan Gizi Olahraga (PAGO) yang diberikan pada subjek, yaitu meliputi kegiatan ADIME yaitu Assessment Gizi (Pengkajian) - Diagnosis Gizi (penentian masalah) - Intervensi Gizi - Monitoring Gizi - Evaluasi Gizi :

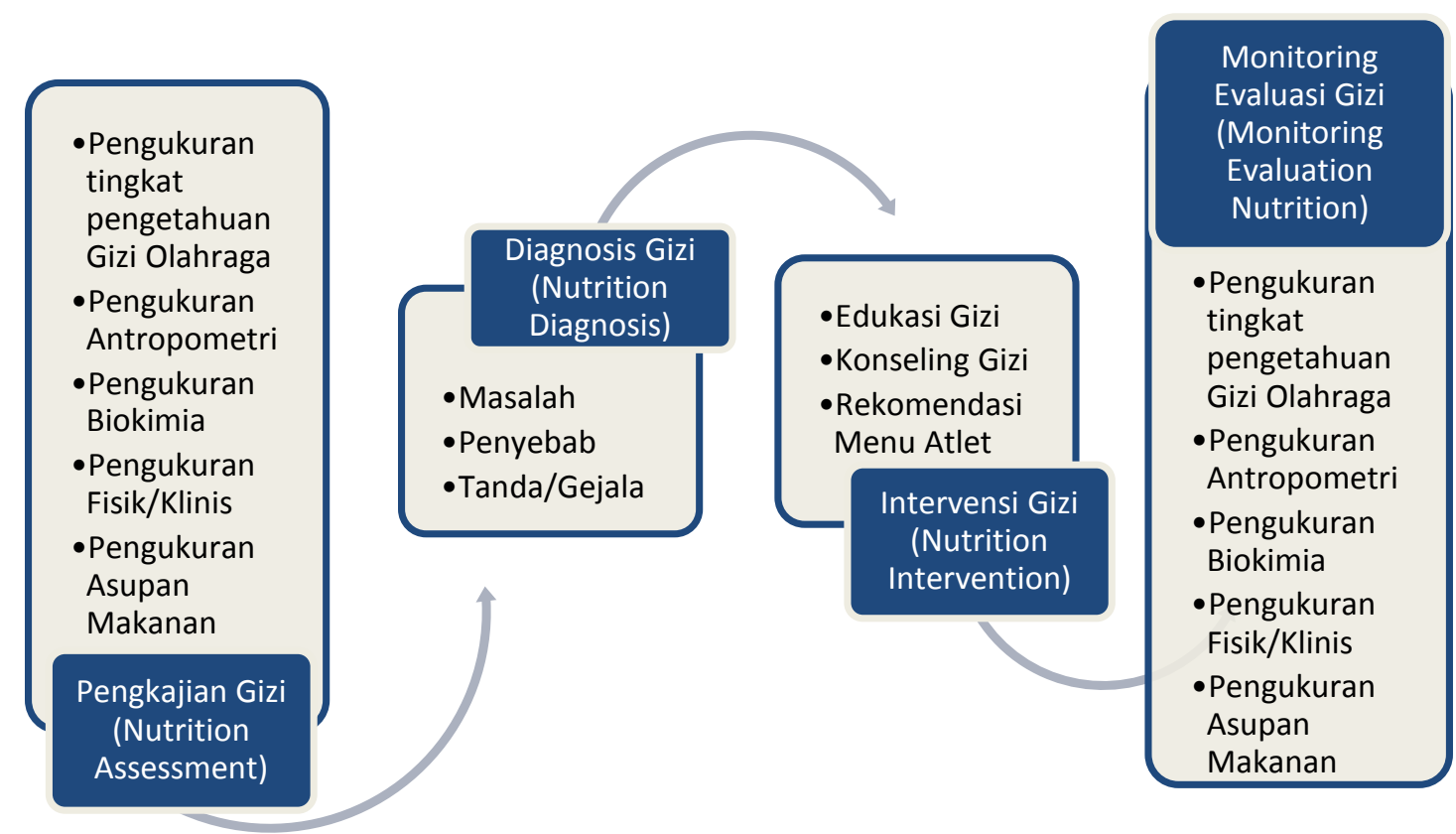

Gambar 1. Alur Proses Asuhan Gizi Olahraga (PAGO)

Hasil pengukuran tingkat pengetahuan gizi olahraga, antropometri, status biokimia, status hidrasi dan asupan subjek sebelum intervensi disajikan pada tabel 2. Sebanyak 54,5\% atlet memiliki tingkat pengetahuan tentang gizi olahraga dengan kategori kurang (skor benar $<60 \%$ ), sedangkan sisanya berpengetahuan gizi kategori cukup. Beberapa atlet yang sering mengikuti kompetisi tingkat nasional maupun internasional sudah terpapar pengetahuan gizi dari pelatih, meskipun hanya terbatas. Namun penerapan dalam perilaku makan atau kualitas diet para atlet tersebut belum optimal.

Seluruh subjek memiliki status gizi normal. Berdasarkan pengukuran persen lemak tubuh, ditemukan 36,4\% subjek yang tergolong underfat. Hasil pengukuran hidrasi menunjukkan sebelum dan setalah latihan terdapat $27,3 \%$ subjek terhidrasi dengan baik.

Pengukuran status biokimia dalam penelitian ini meliputi pengukuran kadar hemoglobin, kadar gula darah puasa, kadar asam urat, dan kadar kolesterol. Pengukuran kadar hemoglobin menunjukkan seluruh subjek memiliki kadar hemoglobin yang normal. Berdasarkan hasil pengukuran kadar gula darah puasa, ditemukan $9,1 \%$ subjek yang tergolong rendah. Hasil pengukuran kadar asam urat, diketahui sebanyak 54,5\% memiliki kadar asam urat yang tergolong tinggi. Dalam penelitian ini juga ditemukan $82,8 \%$ subjek yang memiliki kadar kolesterol tinggi.

Hasil perhitungan asupan energi sebelum intervensi menunjukkan, sebanyak 27,3\% subjek tergolong kurang dan 9,1\% tergolong lebih. Berdasarkan perhitungan asupan karbohidrat, mayoritas subjek, yaitu $82,8 \%$ subjek mengkonsumsi karbohidrat yang kurang dari kebutuhan. Hasil perhitungan asupan lemak menunjukkan sebanyak 63,6\% subjek mengkonsumsi lemak lebih dari kebutuhannya, sedangkan hasil perhitungan asupan protein menunjukkan 54,5\% subjek mangkonsumsi protein kurang dari kebutuhannya dan terdapat 9,1\% subjek yang mengkonsumsi protein lebih dari kebutuhan.

Sebanyak 63,6\% subjek mengkonsumsi cairan kurang dari kebutuhannya. Hasil perhitungan asupan seng ditemukan 36,4\% subjek yang mengkonsumsi kurang dari kebutuhan. Hasil perhitungan asupan besi menunjukkan sebanyak 27,3\% subjek tergolong kurang, sedangkan hasil perhitungan asupan kalsium ditemukan $72,7 \%$ subjek yang tergolong kurang. 
Jurnal Keolahragaan 9 (2), 2021 - 152

Fillah Fithra Dieny, Firdananda Fikri Jauharany, Ayu Rahadiyanti, Deny Yudi Fitranti, A. Fahmy Arif Tsani, Dewi Marfu'ah Kurniawati

Tabel 2. Profil Tingkat Pengetahuan Gizi olahraga, Indeks Massa Tubuh, Persen lemak tubuh, Biokimia, Status Hidrasi dan Asupan Zat Gizi sebelum Intervensi

\begin{tabular}{|c|c|c|}
\hline Kategori & $\mathbf{n}$ & $\%$ \\
\hline \multicolumn{3}{|c|}{ Tingkat Pengetahuan Gizi Olahraga } \\
\hline Kurang & 6 & 54,5 \\
\hline Cukup & 5 & 45,5 \\
\hline Baik & - & - \\
\hline \multicolumn{3}{|c|}{ Status Gizi berdasarkan IMT/U } \\
\hline Normal & 11 & 100 \\
\hline \multicolumn{3}{|l|}{ Persen Lemak Tubuh } \\
\hline Overfat & - & - \\
\hline Normal & 7 & 63,6 \\
\hline Underfat & 4 & 36,4 \\
\hline \multicolumn{3}{|c|}{ Status Hidrasi sebelum Latihan } \\
\hline Kurang terhidrasi & 3 & 27,3 \\
\hline Terhidrasi baik & 3 & 27,3 \\
\hline Dehidrasi & 5 & 45,4 \\
\hline \multicolumn{3}{|c|}{ Status Hidrasi setelah Latihan } \\
\hline Kurang terhidrasi & 4 & 36,7 \\
\hline Terhidrasi baik & 3 & 27,3 \\
\hline Dehidrasi & 4 & 36,7 \\
\hline \multicolumn{3}{|l|}{ Kadar Hemoglobin } \\
\hline Normal & 11 & 100 \\
\hline \multicolumn{3}{|c|}{ Kadar Gula Darah Puasa } \\
\hline Rendah & 1 & 9,1 \\
\hline Normal & 10 & 90,9 \\
\hline \multicolumn{3}{|l|}{ Kadar Asam Urat } \\
\hline Normal & 5 & 45,5 \\
\hline Tinggi & 6 & 54,5 \\
\hline \multicolumn{3}{|l|}{ Kadar Kolesterol } \\
\hline Normal & 2 & 18,2 \\
\hline Tinggi & 9 & 82,8 \\
\hline \multicolumn{3}{|l|}{ Asupan Energi } \\
\hline Kurang & 3 & 27,3 \\
\hline Cukup & 7 & 63,6 \\
\hline Lebih & 1 & 9,1 \\
\hline \multicolumn{3}{|l|}{ Asupan Karbohidrat } \\
\hline Kurang & 9 & 82,8 \\
\hline Cukup & 1 & 9,1 \\
\hline Lebih & 1 & 9,1 \\
\hline \multicolumn{3}{|l|}{ Asupan Lemak } \\
\hline Cukup & 4 & 36,4 \\
\hline Lebih & 7 & 63,6 \\
\hline \multicolumn{3}{|l|}{ Asupan Protein } \\
\hline Kurang & 6 & 54,5 \\
\hline Cukup & 4 & 36,4 \\
\hline Lebih & 1 & 9,1 \\
\hline \multicolumn{3}{|l|}{ Asupan Cairan } \\
\hline Kurang & 7 & 63,6 \\
\hline Cukup & 4 & 36,4 \\
\hline \multicolumn{3}{|l|}{ Asupan Seng } \\
\hline Kurang & 4 & 36,4 \\
\hline Cukup & 7 & 63,6 \\
\hline \multicolumn{3}{|l|}{ Asupan Besi } \\
\hline Kurang & 3 & 27,3 \\
\hline Cukup & 8 & 72,7 \\
\hline \multicolumn{3}{|l|}{ Asupan kalsium } \\
\hline Kurang & 8 & 72,7 \\
\hline Cukup & 3 & 27,3 \\
\hline
\end{tabular}


Jurnal Keolahragaan 9 (2), 2021 - 153

Fillah Fithra Dieny, Firdananda Fikri Jauharany, Ayu Rahadiyanti, Deny Yudi Fitranti, A. Fahmy Arif Tsani, Dewi Marfu'ah Kurniawati

Gizi dan kesehatan yang optimal pada atlet dibutuhkan dalam menunjang latihan dan kompetisi yang baik. Kombinasi antara asupan gizi yang tepat dan latihan fisik yang rutin mampu menghasilkan prestasi atlet yang baik (Budiono, Setiawan, \& Kurnia, 2021). Hal ini dikarenakan energi yang dikeluarkan saat berolahraga seharusnya seimbang dengan energi yang masuk melalui apa yang dikonsumsi oleh atlet, akan tetapi perhatian terhadap pengaturan asupan gizi pada atlet ini masih sangat kurang (Kementerian Kesehatan Republik Indonesia, 2010).

Dalam penelitian ini, pemberian edukasi gizi meliputi konsep gizi dasar, pentingnya asupan gizi terhadap performa dan peningkatan prestasi, serta pemberian contoh menu sehari yang dikembangkan oleh para ahli untuk memudahkan atlet dalam mempelajari konsep gizi olahraga dan mengaplikasikannya pada dirinya dalam kehidupan sehari-hari. Tujuan dari edukasi gizi dalam penelitian ini adalah untuk meningkatkan pengetahuan dan kesadaran atlet dalam merubah perilaku makan yang tepat untuk atlet. Selain itu dalam intervensi gizi juga dilakukan konseling kelompok pada orangtua dan pelatih serta konseling kelompok pada atlet. Untuk menggali hambatan, motivasi dan kemajuan/ progress setiap atlet dalam menerapkan rekomendasi menu yang diberikan maka intervensi gizi juga dilakukan konseling gizi secara personal. Edukasi dan konseling gizi diberikan dengan tujuan meningkatkan pengetahuan gizi pada atlet dan kesadaran dalam merubah perilaku makan (diet) sehingga lebih berkualitas. Pada atlet remaja perlu dipastikan dalam mempertahankan pola makan yang sehat dan citra tubuh yang positif untuk mencapai gaya hidup sehat dan prestasi atletik yang tinggi. Akan tetapi, pemberian edukasi gizi saja tidak mampu menjamin perubahan perilaku yang positif, maka perlu diberikan dorongan (diberikan motivasi) pada atlet untuk mengubah perilaku makan dengan meningkatkan kesadaran dan keterampilan individu atlet melalui konseling yang disesuaikan (Arlinghaus \& Johnston, 2017).

Tabel 3 menunjukkan tingkat pengetahuan atlet sebelum dan sesudah intervensi secara statistik tidak berubah signifikan, namun rerata skor sebelum dan sesudah intervensi mengalami peningkatan dari 12,3 menjadi 15,2. Selain itu ditemukan ada perbedaan pengukuran antropometri status hidrasi, status biokimia, dan asupan gizi atlet antara sebelum dan setelah diberikan intervensi. Hasil pengukuran antropometri, yaitu berat badan $(p=0,029)$ dan fat mass $(p=0,003)$ menunjukkan perbedaan bermakna antara sebelum dan setelah intervensi. Selain itu juga ditemukan perbedaan pada status hidrasi subjek sebelum latihan $(p=0,026)$, namun tidak ada perbedaan signifikan pada status hidrasi subjek setelah latihan $(p=0,208)$. Hasil pengukuran status biokimia, diketahui kadar gula darah $(p=0,005)$ dan kadar hemoglobin $(p=0,007)$ menunjukkan perbedaan bermakna antara sebelum dan setelah intervensi. Berdasarkan perhitungan terhadap asupan subjek, ditemukan perbedaan yang signifikan pada asupan karbohidrat $(p=0,029)$ dan asupan seng $(p=0,049)$ subjek antara sebelum dan setelah intervensi. Perubahan perilaku makan pada atlet setelah pemberian edukasi dan konseling gizi secara berkala juga ditemukan pada hasil penelitian ini. Atlet-atlet dalam penelitian ini memperbaiki kualitas dan kuantitas asupan menyesuaikan dengan kebutuhannya. Perbaikan pola makan ini turut berdampak pada profil antropometri dan status biokimianya.

Tabel 3. Perubahan Profil Antropometri, Biokimia, Status Hidrasi dan Asupan Zat Gizi setelah Intervensi PAGO

\begin{tabular}{|c|c|c|c|}
\hline \multirow[t]{2}{*}{ Variabel } & Sebelum Intervensi & Setelah Intervensi & \multirow[t]{2}{*}{$p$} \\
\hline & Rerata & Rerata & \\
\hline Tingkat pengetahuan gizi (skor) & 12,3 & 15,2 & 0,006 \\
\hline Berat badan (Kg) & 49,3 & 50,4 & $\mathbf{0 , 0 2 9}$ \\
\hline Tingi Badan $(\mathrm{cm})$ & 159,2 & 159,9 & 0,183 \\
\hline Fat Mass $(\mathrm{Kg})$ & 7,3 & 7,9 & $\mathbf{0 , 0 0 3}$ \\
\hline Massa otot (kg) & 37,5 & 71,9 & 0,305 \\
\hline Body water (kg) & 30,2 & 30,3 & 0,859 \\
\hline Status hidrasi sebelum latihan (skor PURI) & 4 & 2 & 0,026 \\
\hline Status hidrasi setelah latihan (skor PURI) & 3 & 2 & 0,208 \\
\hline Kadar gula darah $(\mathrm{g} / \mathrm{dL})$ & 76,5 & 96,3 & 0,005 \\
\hline Kadar asam urat (g/dL) & 5,3 & 5,0 & 0,568 \\
\hline Kadar kolesterol (g/dL) & 250,2 & 222,8 & 0,180 \\
\hline Kadar Hemoglobin (g/dL) & 14,4 & 15,3 & 0,007 \\
\hline Asupan energi (kkal) & 2100 & 2520 & 0,122 \\
\hline Asupan Protein (gram) & 88,6 & 103,3 & 0,294 \\
\hline Asupan Karbohidrat (gram) & 245,8 & 325,6 & $\mathbf{0 , 0 2 9}$ \\
\hline
\end{tabular}


Jurnal Keolahragaan 9 (2), 2021 - 154

Fillah Fithra Dieny, Firdananda Fikri Jauharany, Ayu Rahadiyanti, Deny Yudi Fitranti, A. Fahmy Arif Tsani, Dewi Marfu'ah Kurniawati

\begin{tabular}{lccc}
\hline \multicolumn{1}{c}{ Variabel } & Sebelum Intervensi & Setelah Intervensi & $\boldsymbol{p}$ \\
\cline { 2 - 3 } & Rerata & Rerata & \\
\hline Asupan lemak (gram) & 95,4 & 92,2 & 0,797 \\
Asupan Cairan (ml) & 2700 & 2800 & 0,845 \\
Asupan Seng (mg) & 7,8 & 25,8 & $\mathbf{0 , 0 4 9}$ \\
Asupan Zat besi (mg) & 10,1 & 17,1 & 0,156 \\
Asupan Kalsium (mg) & 761 & 738 & 0,916 \\
\hline
\end{tabular}

Hasil penelitian ini sesuai dengan penelitian terdahulu yaitu pada atlet sepak bola dan atlet renang. Penelitian pada 15 atlet sepak bola dan 15 atlet renang yang diberikan intervensi berupa edukasi dan konseling selama 8 minggu menunjukkan hasil peningkatan pengetahuan gizi, self-efficacy, dan pola makan (Abood, Black, \& Birnbaum, 2004). Beberapa penelitian sebelumnya menunjukkan bahwa edukasi gizi olahraga memberikan efek positif pada pengaturan berat badan serta aktivitas fisik sehingga mampu meningkatkan kebugaran (Annesi, 2013; Barreira, Harrington, \& Katzmarzyk, 2014; Bird, 2010). Penelitian di Kanada, juga menunjukkan bahwa pemberian edukasi gizi pada pelatih dapat memberikan dampak pada performa atlet yang lebih baik (Ahuja \& Bharti, 2014; Gibson, Gaul, \& Janzen, 2011; Royall, 2015).

Perbedaan yang signifikan pada berat badan dan fat mass subjek antara sebelum dan setelah intervensi ditemukan dalam hasil penelitian ini. Rerata berat badan meningkat dari 49,3 kg menjadi 50,4 $\mathrm{kg}$ sedangkan rerata fat mass meningkat dari $7,3 \mathrm{~kg}$ menjadi $7,9 \mathrm{~kg}$. Monitoring profil antropometri dan status gizi dibutuhkan untuk mempertahankan derajat kebugaran dan kesehatan (MZ, B, \& Tiwuk, 2015; Sepriadi, 2017) Salah satu upaya mencegah masalah gizi dapat dilakukan dengan memberikan pendidikan atau pendampingan yang dilakukan melalui penyuluhan, konseling dan sebagainya. Hal tersebut disebabkan karena pengaruhnya terhadap peningkatan pengetahuan, kesadaran maupun perubahan perilaku untuk mencapai keadaan gizi dan kesehatan optimal (Nurmasyita, Widjanarko, \& Margawati, 2015). Dalam rangka mengoptimalkan performa atlet perlu diperhatikan ukuran, bentuk, dan komposisi tubuh yang tepat. Ukuran, bentuk, dan komposisi tubuh biasanya diperlukan untuk menentukan dan mengkualifikasikan karakteristik fisiologis atlet (Moses \& Duduyemi, 2016). Komposisi tubuh yang terjaga pada atlet akan memberikan manfaat kesehatan yang luar biasa, seperti efisiensi otot jantung, menurunkan risiko penyakit jantung koroner, mencegah kelebihan berat badan dan obesitas, varises, meningkatkan hemoglobin serta meningkatkan kapasitas fungsional kardiorespirasi (Qureshi et al., 2015). Selain keterampilan individu dan kemampuan mental, karakteristik fisik atlet telah terbukti memiliki pengaruh yang luar biasa terhadap tingkat performa (Anup, Nahida, Islam, \& Kitab, 2014).

Pengukuran kadar gula darah puasa menunjukkan perbedaan bermakna antara sebelum dan sesudah diberikan intervensi. Rerata kadar gula darah puasa sebelum intervensi adalah $76,5 \mathrm{mg} / \mathrm{dL}$, sedangkan setelah intervensi menjadi $96,3 \mathrm{mg} / \mathrm{dL}$. Meskipun rerata kadar gula darah puasa mengalami peningkatan, namun masih dalam rentang yang normal. Olahraga merupakan perpaduan kompleks dari performa keterampilan motorik, proses kognitif, dan waktu reaksi, yang semuanya dipengaruhi oleh kadar glukosa darah. Sebuah penelitian menunjukkan bahwa performa olahraga pada atlet muda paling tinggi ketika kadar glukosa darah berada dalam kisaran normal. Penelitian tersebut juga menunjukkan adanya penurunan performa pada kelompok yang mengalami hipoglikemia (Kelly, Hamilton, \& Riddell, 2010).

Selama olahraga regulasi kadar glukosa darah dipengaruhi oleh tiga hal, yaitu sensitivitas insulin, pola makan dan berbagai adaptasi hormonal tambahan (Lippi, Montagnana, Salvagno, \& Guidi, 2008). Latihan fisik dapat memperkuat sensitivitas insulin, melalui beberapa adaptasi dalam transportasi dan metabolisme glukosa. Latihan fisik mampu meningkatkan penyimpanan glukosa yang distimulasi oleh insulin, baik pada subjek non-diabetes dan penderita diabetes. Selain itu, olahraga juga mampu meningkatkan aktivitas reseptor insulin, yang mengarah pada terjadinya peningkatan aktivasi glikogen sintase pada subjek non-diabetes, sehingga dapat menyebabkan pembuangan glukosa terstimulasi insulin yang lebih besar. Oleh karena itu, atlet menjalani adaptasi metabolik yang positif, meliputi peningkatan penyimpanan glukosa karena peningkatan konsentrasi glikogen otot rangka dan peningkatan laju sintesis glikogen setelah latihan. Meningkatnya penyimpanan glukosa berperan dalam meningkatkan pembuangan glukosa tubuh saat melakukan latihan. 


\section{Jurnal Keolahragaan 9 (2), 2021 - 155}

Fillah Fithra Dieny, Firdananda Fikri Jauharany, Ayu Rahadiyanti, Deny Yudi Fitranti, A. Fahmy Arif Tsani, Dewi Marfu'ah Kurniawati

Pemeriksaan kadar hemoglobin juga menunjukkan perbedaan bermakna antara sebelum dan setelah dilakukan intervensi. Rerata kadar hemoglobin meningkat dari $14,4 \mathrm{mg} / \mathrm{dL}$ menjadi $15,3 \mathrm{mg} / \mathrm{dL}$ yang menunjukkan kadar hemoglobin tergolong normal. Kadar hemoglobin menggambarkan simpanan zat besi dalam tubuh. Zat besi merupakan salah satu zat penting untuk berbagai fungsi biologis, seperti reaksi transfer elektron, pengikatan dan pengangkutan oksigen, regulasi gen, regulasi pertumbuhan dan diferensiasi sel. Sebuah penelitian menunjukkan bahwa olahraga berhubungan dengan status zat besi (Koehler et al., 2012; Reinke et al., 2012). Zat besi memiliki peran yang penting dalam transportasi oksigen karena dibutuhkan untuk pembentukan hemoglobin. Zat besi dibutuhkan untuk fungsi optimal dari berbagai enzim oksidatif yang mempengaruhi metabolisme intraseluler, yaitu rantai transpor elektron serta jalur fosforilasi oksidatif di mitokondria (Beard, 2001). Aktivitas fisik durasi pendek seperti sprint dan latihan aerobik yang berkepanjangan juga dapat mempengaruhi mekanisme tersebut (Rowland, 2012). Hal tersebut mengakibatkan status besi terganggu yang memberikan dampak negatif pada kinerja fisik. Oleh sebab itu, harus dilakukan pemantauan berkala kadar hemoglobin pada atlet. Kadar hemoglobin yang normal pada atlet juga harus dipertahankan untuk mengoptimalkan performanya.

Asupan karbohidrat antara sebelum dan setelah intervensi ditemukan berbeda signifikan $(\mathrm{p}=0,029)$, dimana terdapat peningkatan asupan karbohidrat dari 245,8 gram/hari menjadi 325,6 gram/hari. Karbohidrat adalah salah satu zat gizi yang penting dalam pemulihan dan performa olahraga (Thomas, Erdman, \& Burke, 2016). Asupan karbohidrat yang cukup perlu diperhatikan, baik sebelum pertandingan maupun setelah pertandingan (Mirza Hapsari Sakti Titis Penggalih, Solichah, et al., 2018). Pada atlet asupan karbohidrat bermanfaat untuk meningkatkan kinerja atletik melalui penyediaan substrat bahan bakar, mendukung sistem imun serta meningkatkan bioavaibilitas zat gizi lain (Maughan et al., 2018). Ketika melakukan olahraga dengan intensitas tinggi, karbohidrat menjadi substrat energi utama, sehingga penipisan glikogen dianggap sebagai faktor pembatas penting dari kinerja (Noakes, 2000). Ketersediaan karbohidrat eksogen yang tinggi saat latihan berlangsung (kira-kira 78-90 gram/jam) mampu memfasilitasi kinerja melalui penghematan glikogen pada hati, menghindari risiko terjadinya hipoglikemia dan melalui pemeliharaan yang tinggi (Jeukendrup, 2011; Smith et al., 2013).

Dalam penelitian ini diketahui terdapat peningkatan asupan zink pada subjek dari 7,8 gram/hari menjadi 25,8 gram/hari. Berdasarkan Angka Kecukupan Gizi (AKG) tahun 2013 rekomendasi kecukupan asupan zink pada kelompok umur 10-18 tahun adalah 14-18 mg/hari untuk laki-laki dan 13$16 \mathrm{mg} /$ hari untuk perempuan (Kementerian Kesehatan Republik Indonesia, 2013). Sehingga, dapat disimpulkan bahwa, setelah pemberian edukasi dan konseling gizi secara berkala, asupan zink subjek dalam penelitian ini telah memenuhi kecukupan zink yang direkomendasikan. Status zink mampu mempengaruhi performa pada atlet (Mirza Hapsari Sakti Titis Penggalih, Dewinta, et al., 2018). Penelitian pada atlet sepakbola menunjukkan hasil bahwa atlet yang memiliki kadar serum zink rendah (hipozincemia) mengalami penurunan performa dan mengalami peningkatan viskositas darah yang disebabkan oleh peningkatan fragilitas eritrosit (Khaled, Brun, Cassanas, Bardet, \& Orsetti, 1999). Hal ini berkaitan dengan kadar serum zink yang rendah yang menyebabkan terjadinya penurunan peak power output dan penurunan lactate threshold sehingga dapat mengurangi kekuatan otot dan kapasitas latihan (Wolinsky \& Driskell, 2005).

Program Asuhan Gizi olahraga pada atlet merupakan proses asuhan yang berkesinambungan yang sangat dibutuhkan atlet untuk mengetahui, menganalisis permasalahan atlet dan memberikan solusi sesuai dengan masalah yang dihadapi atlet masing masing dan dapat dievaluasi hambatan dalam perubahan perilaku, kemajuan dan pencapaian yang dialami atlet. Program ini perlu dikembangkan di pusat pendidikan dan latihan olahraga berbagai daerah agar atlet, pelatih maupun orang tua menyadari pentingnya gizi dalam menunjang performa dan tumbuh kembang atlet remaja.

\section{SIMPULAN}

Pemberian Program Asuhan Gizi Olahraga (PAGO) dapat memperbaiki profil antropometri, status biokimia, dan asupan atlet sepatu roda. Peningkatan Frekuensi dan durasi latihan atlet sebaiknya disertai dengan pendampingan ahli gizi untuk memantau status gizi dan asupan makanan atlet serta memberikan edukasi dan konseling gizi secara berkala. Hal ini bertujuan agar kualitas diet, status gizi, dan kesehatan atlet tetap terjaga, sehingga menghasilkan performa yang optimal. 


\section{Jurnal Keolahragaan 9 (2), 2021 - 156}

Fillah Fithra Dieny, Firdananda Fikri Jauharany, Ayu Rahadiyanti, Deny Yudi Fitranti, A. Fahmy Arif Tsani, Dewi Marfu'ah Kurniawati

\section{DAFTAR PUSTAKA}

Abood, D. A., Black, D. R., \& Birnbaum, R. D. (2004). Nutrition Education intervention for College Female Athletes. Journal of Nutrition Education and Behavior, 36(3), 135-137. Retrieved from https://doi.org/10.1016/s1499-4046(06)60150-4

Ahuja, P., \& Bharti, V. (2014). Nutrition Knowledge of Football Players and Formulation of an Effective Nutrition Communication Package. International Journal of Food, Nutrition and Dietetics, 2(2).

Annesi, J. J. (2013). Association of multimodal treatment-induced improvements in stress, exercise volume, nutrition, and weight with improved blood pressure in severely obese women. International Journal of Behavioral Medicine, 20(3), 397-402. Retrieved from https://doi.org/10.1007/s12529-012-9240-7

Anup, A., Nahida, P., Islam, R. N., \& Kitab, A. (2014). Importance of Anthropometric Characteristics in Athletic Performance from the Perspective of Bangladeshi National Level Athletes' Performance and Body Type. American Journal of Sports Science and Medicine, 2(4), 123-127. https://doi.org/10.12691/ajssm-2-4-1

Arlinghaus, K. R., \& Johnston, C. A. (2017). Advocating for Behavior Change. American Journal of Lifestyle Medicine, 12(2), 113-116. https://doi.org/10.1177/1559827617745479.

Barreira, T. V, Harrington, D. M., \& Katzmarzyk, P. T. (2014). Cardiovascular Health Metrics and Accelerometer-Measured Physical Activity Levels: National Health and Nutrition Examination Survey, 2003-2006. Mayo Clinic Proceedings, 89(1), 81-86.

Beard, J. L. (2001). Iron-Deficiency Anemia : Reexamining the Nature and Magnitude of the Public Health Problem. Iron Biology in Immune Function, Muscle Metabolism. American Society for Nutritional Sciences, 568-580.

Bingham, M. E., Borkan, M. E., \& Quatromoni, P. A. (2016). Sports Nutrition Advice for Adolescent Athletes : A Time to Focus on Food. American Journal of Lifestyle Medicine, 9(6), 398-402. https://doi.org/10.1177/1559827615598530

Bird, S. (2010). Strength Nutrition: Maximizing Your Anabolic Potential. Strength and Conditioning Journal, 32(4), 80-86. Retrieved from https://doi.org/10.1519/SSC.0b013e3181d5284e

Budiono, I., Setiawan, A., \& Kurnia, A. R. (2021). The use participatory action research to improve energy intake of the soccer athletes. Jurnal Keolahragaan, 9(1), 76-85.

Carl, R. L., Johnson, M. D., Martin, T. J., \& AAP COUNCIL ON SPORTS MEDICINE AND FITNESS. (2017). Promotion of Healthy Weight- Control Practices in Young Athletes. Pediatrics, 140(3).

Gibson, J. C., Gaul, C., \& Janzen, J. (2011). Education and training of sport dietitians in Canada: A review of current practice. Canadian Journal of Dietetic Practice and Research, 72(2), 88-91. Retrieved from https://doi.org/10.3148/72.2.2011.88

Hermawan, A. N. (2015, May 29). Tingkatkan Teknik, 11 Atlet Sepatu Roda Berguru ke Taiwan. Antara Jateng. Retrieved from https://jateng.antaranews.com/berita/119387/tingkatkan-teknik11-atlet-sepatu-roda-berguru-ke-taiwan

Jeukendrup, A. E. (2011). Nutrition for endurance sports: Marathon, triathlon, and road cycling. Journal of Sports Sciences, 29, 91-99. Retrieved from https://doi.org/10.1080/02640414.2011.610348

Kelly, D., Hamilton, J. K., \& Riddell, M. C. (2010). Blood Glucose Levels and Performance in a Sports Camp for Adolescents with Type 1 Diabetes Mellitus : A Field Study. International Journal of Pediatrics, 2010, 1-8. https://doi.org/10.1155/2010/216167

Kementerian Kesehatan Republik Indonesia. (2010). Panduan Kesehatan Olahraga Bagi Petugas Kesehatan. Retrieved from http://www.depkes.go.id/ 


\section{Jurnal Keolahragaan 9 (2), 2021 - 157}

Fillah Fithra Dieny, Firdananda Fikri Jauharany, Ayu Rahadiyanti, Deny Yudi Fitranti, A. Fahmy Arif Tsani, Dewi Marfu'ah Kurniawati

Kementerian Kesehatan Republik Indonesia. (2013). Angka Kecukupan Gizi yang Dianjurkan Bagi Bangsa Indonesia Tahun 2013.

Khaled, S., Brun, J. F., Cassanas, G., Bardet, L., \& Orsetti, A. (1999). Effects of zinc supplementation on blood rheology during exercise. Clinical Hemorheology and Microcirculation, 20(1), 1-10.

Koehler, K., Braun, H., Achtzehn, S., Hildebrand, U., Predel, H.-G., Mester, J., \& Schänzer, W. (2012). Iron status in elite young athletes: Gender-dependent influences of diet and exercise. European Journal of Applied Physiology, 112(2), 513-523. Retrieved from https://doi.org/10.1007/s00421-011-2002-4

Lippi, G., Montagnana, M., Salvagno, G. L., \& Guidi, G. C. (2008). Glycaemic Control in Athletes. International Journal of Sports Medicine, 29, 7-10. https://doi.org/10.1055/s-2007-964898

Maughan, R. J., Burke, L. M., Dvorak, J., Larson-meyer, D. E., Peeling, P., Phillips, S. M., ... Pitsiladis, Y. P. (2018). IOC consensus statement: dietary supplements and the high-performance athlete. Journal Sports Medi, 52, 439-455. https://doi.org/10.1136/bjsports-2018-099027

Moses, M. O., \& Duduyemi, B. M. (2016). Sports Participation, Anthropometric and Physiological Profiles of University Athletes. Nigerian Iournal of Physiological Sciences, 31, 063-069.

MZ, N. A., B, K. N., \& Tiwuk, S. (2015). Pengaruh Status Nutrisi Terhadap Kebugaran Fisik Atlit Karate di Bandar Lampung. J MAJORITY, 4(6), 1-4.

Nelson, M. C., Story, M., Larson, N. I., Neumark-Sztainer, D., \& Lytle, L. A. (2008). Emerging adulthood and college-aged youth: An overlooked age for weight-related behavior change. Obesity (Silver Spring), 16(10), 2205-2211. Retrieved from https://doi.org/10.1038/oby.2008.365

Noakes, T. D. (2000). Physiological models to understand exercise fatigue and. Journal of Medicine and Science in Sports, 10, 123-145. https://doi.org/10.1034/j.1600-0838.2000.010003123.x

Nurmasyita, Widjanarko, B., \& Margawati, A. (2015). Pengaruh intervensi pendidikan gizi terhadap peningkatan pengetahuan gizi , perubahan asupan zat gizi dan indeks massa tubuh remaja kelebihan berat badan. Jurnal Gizi Indonesia, 4(1), 38-47.

Patton-Lopez, M. M., Manore, M. M., Branscum, A., Meng, Y., \& Wong, S. S. (2018). Changes in Sport Nutrition Knowledge, Attitudes/Beliefs and Behaviors Following a Two-Year Sport Nutrition Education and Life-Skills Intervention among High School Soccer Players. Nutrients, 10(11), 1636. Retrieved from https://doi.org/10.3390/nu10111636

Penggalih, Mirza Hapsari Sakti Titis, Dewinta, M. C. N., Fikriyah, C. K., Kustia, N., Zada, A. R., Sofro, Z. M., \& Kandarina, B. J. I. K. (2018). Pengaruh suplementasi zink terhadap parameter hematologi atlet sepatu roda setelah latihan e ndurance. Junral Gizi Klinik Indonesia, 15(1), 28 36.

Penggalih, Mirza Hapsari Sakti Titis, Solichah, K. M., Pratiwi, D., Niamilah, I., Dewinta, M. C. N., Nadia, A., ... Asyulia, R. (2018). Identifikasi profil antropometri dan pemenuhanzat gizi atlet difabel tenis meja di Indonesia. Jurnal Keolahragaan, 6(2), 162-171.

Penggalih, Miza Hapsari Sakti Titis, \& Huriyati, E. (2007). Gaya Hidup, Status Gizi dan Stamina Atlet pada Sebuah Klub Sepakbola. Berita Kedokteran Masyarakat, 23(4), 192-199.

Qureshi, W. T., Alirhayim, Z., Blaha, M. J., Juraschek, S. P., Keteyian, S. J., Brawner, C. A., \& AlMallah, M. H. (2015). Cardiorespiratory Fitness and Risk of Incident Atrial Fibrillation: Results From the Henry Ford Exercise Testing (FIT) Project. Circulation, 131(21), 1827-1834. Retrieved from https://doi.org/10.1161/CIRCULATIONAHA.114.014833

Reinke, S., Taylor, W. R., Duda, G. N., Von Haehling, S., Reinke, P., Volk, H.-D., ... Doehner, W. (2012). Absolute and functional iron deficiency in professional athletes during training and recovery. International Journal of Cardiology, 156(2), 186-191. Retrieved from https://doi.org/10.1016/j.ijcard.2010.10.139 


\section{Jurnal Keolahragaan 9 (2), 2021 - 158}

Fillah Fithra Dieny, Firdananda Fikri Jauharany, Ayu Rahadiyanti, Deny Yudi Fitranti, A. Fahmy Arif Tsani, Dewi Marfu'ah Kurniawati

Rhaisa, G., Carvalho, F. De, Vargas, S., Chagas, S., \& Toral, N. (2017). Nutritional interventions for adolescents using information and communication technologies ( ICTs ): A systematic review. PLoS ONE, 12(9), 1-12. https://doi.org/e0184509

Rowland, T. (2012). Iron Deficiency in Athletes: An Update. American Journal of Lifestyle Medicine, 6(4), 319-327. Retrieved from https://doi.org/10.1177/1559827611431541

Royall, D. (2015). Nutrition Support for Athletes. Canadian Journal of Dietetic Practice and Research, 76(3), 102-102. Retrieved from https://doi.org/10.3148/cjdpr-2015-023

Saputra, B. A., \& Indra, E. N. (2019). Profil Kondisi Fisik Atlet Sepatu Roda Daerah Istimewa Yogyakarta. MEDIKORA, XVIII(2), 70-78.

Sepriadi, S. (2017). Kontribusi Status Gizi dan Kemampuan Motorik terhadap Kesegaran Jasmani Siswa Sekolah Dasar. Jurnal Keolahragaan, 5(2), 194-206.

Smith, J. W., Pascoe, D. D., Passe, D. H., Ruby, B. C., Stewart, L. K., Baker, L. B., \& Zachwieja, J. J. (2013). Curvilinear Dose-Response Relationship of Carbohydrate (0-120 gIhj1) and Performance. Journal of the American College of Sport Medicine, 1, 336-341. https://doi.org/10.1249/MSS.0b013e31827205d1

Suharno, H. (1992). Ilmu Kepelatihan Olahraga. Yogyakarta: IKIP Yogyakarta.

Thomas, D. T., Erdman, K. A., \& Burke, L. M. (2016). Position of the Academy of Nutrition and Dietetics, Dietitians of Canada, and the American College of Sports Medicine: Nutrition and Athletic Performance. Journal of the Academy of Nutrition and Dietetics, 116(3), 501-528. Retrieved from https://doi.org/10.1016/j.jand.2015.12.006

Wolinsky, I., \& Driskell, J. A. (2005). Sports Nutrition: Vitamins and Trace Elements (2nd ed.). CRC Press. Retrieved from https://www.routledge.com/Sports-Nutrition-Vitamins-and-TraceElements-Second-Edition/Wolinsky-Driskell/p/book/9780367453985

Zuniga, K. E., Downey, D. L., McCluskey, R., \& Rivers, C. (2017). Need for and Interest in a Sports Nutrition Mobile Device Application Among Division I Collegiate Athletes. International Journal of Sport Nutrition and Exercise Metabolism, 27(1), 43-49. Retrieved from https://doi.org/10.1123/ijsnem.2015-0305 